\title{
Vermicast of Earthworm as Ecosystem Engineers within Different Vermireactor Shape
}

\author{
Laode Muhammad Harjoni Kilowasid ${ }^{1 *}$, Muhammad Fahyu Sanjaya ${ }^{1}$, Tresjia C. Rakian ${ }^{1}$, \\ Syamsu Alam², Muhammad Kabil Djafar ${ }^{3}$ and Muliddin ${ }^{4}$ \\ ${ }^{1}$ Department of Agrotechnology, Faculty of Agriculture, ${ }^{2}$ Department of Soil Science, Faculty of Agriculture, \\ ${ }^{3}$ Department of Mathematics, Faculty of Earth Science and Technology, ${ }^{4}$ Department of Geological Engineering, \\ Faculty of Mathematics and Natural Science, Halu Oleo University, Jl. HEA Mokodompit, \\ Kendari City 93231, Southeast Sulawesi, Indonesia.*e-mail: lohardjoni2@yahoo.co.id
}

Received November 30, 2019; Revised March 5, 2020; Accepted 6 March 2020

\begin{abstract}
Earthworms as ecosystem engineers can modify the quality of vermibed assembled from mixed soil with organic material in a vermireactor. Various in shapes of the vermireactor are used to produce a vermicast for biofertilizer in agriculture. The objective of this research was to study the vermicast production and its quality produced from a variety of vermireactor shapes. Earthworm (Pheretima sp.) which was applied to the vermireactor consists of: withand without of earthworms. Three shapes of the vermireactor, namely cylinder, square, and rectangular has been tested. Compost of Chromolaena odorata pruning mixed with soil was used as vermibed. The vermicast process ran until 28 days. The results showed that vermireactor with earthworms which were successfully converted to vermicast was about $49.24 \%$ from the vermibed volume, however, no vermicast formed was found from vermireactor without earthworms. The difference in vermicast produced from different vermireactor shapes was not significant. The value of $\mathrm{pH}$, total- $\mathrm{N}$, and $\mathrm{C} / \mathrm{N}$ ratio among the vermicast was different. The number of the morphological character of bacteria colonies in the vermicast produced from the square vermireactor was the highest, while from cylinder vermireactor was the lowest. We concluded that the quality of vermicast from earthworm (Pheretima sp.) activity was determined by the shape of the vermireactor.
\end{abstract}

Keywords: Ecosystem engineers, quality, vermibed, vermicast, vermireactor

\begin{abstract}
ABSTRAK
Cacing tanah sebagai perekayasa ekosistem memiliki kemampuan memodifikasi kualitas vermibed yang tersusun dari campuran tanah dengan bahan organik dalam suatu vermireaktor. Bermacam bentuk vermireaktor sering digunakan untuk memproduksi vermicast sebagai pupuk hayati di bidang pertanian. Tujuan dari penelitian ini adalah untuk mempelajari produksi vermicast dan kualitasnya yang dihasilkan dari berbagai bentuk vermireaktor. Perlakuan cacing tanah (Pheretima sp.) yang diaplikasi dalam vermireaktor terdiri dari: dengan dan tanpa cacing tanah. Ada tiga bentuk vermireaktor, yakni silinder, persegi, dan persegi panjang yang telah diuji. Kompos dari pangkasan Chromolaena odorata yang dicampur dengan tanah digunakan sebagai vermibed. Proses vermicasting berlangsung hingga 28 hari. Hasilnya adalah sekitar 49,24\% dari volume vermibed dalam vermireaktor dengan cacing tanah berhasil dikonversi menjadi vermicast, sedang vermireaktor tanpa cacing tanah tidak ditemukan vermicast yang terbentuk. Perbedaan jumlah vermicast yang dihasilkan dari ketiga bentuk vermireaktor tidak signifikan. Nilai $\mathrm{pH}, \mathrm{N}$-total, dan rasio $\mathrm{C} / \mathrm{N}$ antara vermicast berbeda. Jumlah karakter morfologi koloni bakteri dalam vermicast yang dihasilkan dari vermireaktor kubus adalah yang tertinggi, sedangkan dari vermireaktor silinder adalah yang terendah. Disimpulkan bahwa kualitas vermicast dari aktivitas cacing tanah (Pheretima sp.) ditentukan oleh bentuk vermireaktor.
\end{abstract}

Kata kunci: Kualitas, perekayasa ekosistem, vermibed, vermicast, vermireaktor

J Trop Soils, Vol. 25, No. 2, 2020: 83-92

ISSN 0852-257X; E-ISSN 2086-6682 


\section{INTRODUCTION}

The earthworm has two functional roles, namely as decomposer and as soil ecosystem engineer (Jones et al. 1994, Pathma and Sakthivel 2012). The concept of its first role has been implemented in vermicomposting technology to process organic solid waste in an urban or agricultural area (Aalok et al. 2008, Singh et al. 2011). Many organic materials including solid organic waste, manure, feces, biochar, or compost can be used as vermibed to be decomposed and transformed into stable organic material through co-activity between earthworm and microorganism in a vermireactor (Tognetti et al. 2005; Nair et al. 2006; Lazcano et al. 2008; Hanc and Pliva 2013; Hanc and Vasak 2014). Such a product is known as vermicompost (Aira et al. 2011; Pathma and Sakthivel 2012). It contains a population of beneficial microbes, available nutrients as well as biostimulant promoting plant growth and suppressing the pathogen (Pathma and Sakthivel 2012; Rekha et al. 2018). Due to its rich content, vermicompost has been utilized as a biofertilizer to improve soil fertility, to amend soil quality, and to increase plant growth (Hanc and Pliva 2013).

The last role concept has been mostly applied to restore the soil quality and fertility (Wodika et al. 2014; Kilowasid et al. 2015; Singh et al. 2016). The earthworm is capable of mixing soil particles with organic material, as well as modifying soil environment, to create a new more appropriate environmental condition to modulate the growth of some useful microbes (Jouquet et al. 2006; Lavelle et al. 2016). Organic material is biochemically degraded by soil microorganisms mutualistic associating with earthworm guts (Edwards and Fletcher 1988). The mix of degraded soil particles and organic material in the intestines configures a biogenic structure (biostructure) in the form of vermicast, and it is released into the soil through the anus (Mora et al. 2006; Hoeffner et al. 2018). Vermicast contains some nutrients, vitamins, enzymes, and various advantageous microbes (Sim and $\mathrm{Wu} 2010$ ). Some beneficial microbes found in vermicast are plant growth-promoting bacteria (such as Azosprillum, Azotobacter, Pseudomonas), and viable spores of arbuscular mycorrhizal fungi (AMF) (Reddell and Spain 1991, Pandya et al. 2014, Vijayabharathi and Sathya 2015). Thus, vermicast has a chance to be utilized as a carrier for the inoculum of beneficial soil bacteria and spore of AMF for agriculture, forestry, and recovery of degraded soil (Harinikumar and Bagyaraj 1994; Sekar and Karmegam 2010; Douds Jr et al. 2014).

In practice, there are three common-used twodimensional figures of vermireactor to produce vermicompost or vermicast, i.e. cylinder, square, and rectangular for creating cylindrical, cube, and beam vermireactors, respectively (Subramanian et al. 2010; Raphael and Velmourougane 2011; Huang et al. 2014; Nigussie et al. 2016). The understanding of production and quality of vermicast produced from various two-dimensional figures of vermireactor can assist in choosing the proper shape of vermireactor to generate vermicast on-field or farm level. The productivity of vermicast from vermireactor is strongly determined by surface area and volume (ratio of surface area and volume) of those vermireactors (Ganesh et al. 2009). Meanwhile, the information regarding the production and quality of produced vermicast from various shapes of vermireactors with similar areas of twodimensional and vermibed volume is rarely reported. Theoretically, the minimum surface area of each two-dimensional figures of those vermireactors is reached in the same volume and at stationary state. On the minimum condition, the surface area of the cylindrical is the smallest; while the surface area of the beam is the largest. Consequently, under such conditions, a ratio of the surface area of the cylindrical on volume is smaller compared to the ratio of the surface area of a cube on volume, and the ratio of the surface area of a cube on volume is smaller than a ratio of the surface area of a beam on volume.

This research was conducted to study the variation of production and quality of vermicast from three different shapes of vermireactors possessing the similarity in surface area of two-dimensional figures and volume of vermibed.

\section{MATERIALS AND METHODS}

\section{Simple Reactor of Cardboard}

Three reactors with different two-dimensional figures were made from cardboards, such as cylinder, square, and rectangular for cylindrical, cube, and beam reactors, respectively. To generate a relatively similar area in each two-dimensional figure, i.e. approximately $144 \mathrm{~cm}^{2}$, the reactor was built from the two-dimensional figure of cylinder, square, and rectangular with $23.7 \mathrm{~cm}$ in diameter, $21 \mathrm{~cm} \times 21 \mathrm{~cm}$ and $25 \mathrm{~cm} \times 17.64$ $\mathrm{cm}$ in dimensions, respectively. Different 
vermireactor from each shape was formed with a height dimension of $21 \mathrm{~cm}$. The interior of each vermireactor was covered with transparent duct tape to protect the vermireactor from damage during the vermicast process.

\section{Compost Production}

Vermibed was comprised of soil spiked with compost from pruned $C$. odorata. Composting of pruned $C$. odorata was processed using a suspension of fermented microorganisms following the procedure of Formowitz et al. (2007). Total of $3 \mathrm{~kg}$ of sliced ( $\pm 1 \mathrm{~cm}$ in size) banana corm, $650 \mathrm{~g}$ of brown sugar, 2 liters of starch water, and 1 liter of water was put into 10 liter-volume of a plastic bucket and stirred using a wood stirrer. The top surface of the bucket was covered with black plastic, and a small hole was provided on the cover for hose connecting the solution in the bucket with water in 1 liter-volume plastic bottle which was placed around the bucket. After 10 days of fermentation, the solution was filtered using a sieve with $0.2 \mathrm{~mm}$ per hole in size, then put into a plastic bottle and kept at room temperature until ready for use. A total of $100 \mathrm{~kg}$ of chopped fresh pruned $C$. odorata $( \pm 3 \mathrm{~cm}$ per slice) and $50 \mathrm{~kg}$ of fine sawdust were manually mixed using shovel and hoe on the surface of a tarp with 4 $\mathrm{m} \times 6 \mathrm{~m}$ in dimension. Those mixtures were moisturized with the diluted stock solution using tap water up to a concentration of $75 \%$ ( $75 \mathrm{cc} /$ liter of tap water). All of the moist materials stirred until relatively homogeneous, and the material wrapped in the tarp. The compost material at any time stirred during the composting period. The composting process was conducted over 30 days, and the mature compost is ready for use.

\section{Experiment Design}

The experiment was performed following the split-plot design in the Laboratory of Biodiversity, Faculty of Agriculture, University of Halu Oleo, Kendari (Indonesia). The main plot consisted of without and with earthworms (Pheretima sp.), and sub-plots were three shapes of vermireactors, i.e. cylindrical, cube, and beam. Each treatment was repeated three times following a randomized completed block design. Compost made from pruned C. odorata was put into each vermireactor up to the height of $3 \mathrm{~cm}$, then the soil from vegetation area of $C$. odorata was placed on the surface of compost layer of $3 \mathrm{~cm}$ in height. This procedure produced total volume filled with vermibed for each vermireactor around $2.646 \mathrm{~cm}^{3}$. The material in each vermireactor was mixed until homogenous. Five starved-earthworms (Pheretima sp.) with clitellum character and body length of $6 \mathrm{~cm}-9 \mathrm{~cm}$ in range were released on the surface of vermibed in each vermireactor. After all parts of earthworm were penetrated vermibed, the surface of each reactor was covered with a plastic screen (size of 2 $\mathrm{mm}$ per hole). The moisture of vermibed in each vermireactor was kept by spraying the water every two days. Besides, the dead earthworm and cocoon were also checked. Vermicasting process was conducted for 28 days. Vermibed was taken out of each vermireactor and placed into different plastic buckets. The earthworm and cocoon were sorted out from vermibed using a hand sorting technique. Furthermore, vermibed was also sorted using the same technique to separate vermicast from nonvermicast, and each weight was measured.

\section{Production and Quality of Vermicast}

Production of vermicast from each shape of vermireactor was determined according to the percentage of successfully converted vermibed into vermicast. Such percentage of vermibed $(\%, w / w)$ was calculated using formula:

$$
\% \text { vermicast }=\frac{\text { vermicast weight }}{\text { vermicast weight }+ \text { non }- \text { vermicast weight }} \times 100 \%
$$

The quality of vermicast was measured through some parameters such as $\mathrm{pH}$, organic- $\mathrm{C}$, total- $\mathrm{N}$, $\mathrm{C} / \mathrm{N}$ ratio, $\mathrm{P}_{2} \mathrm{O}_{5}$, and the number of morphological characters of bacterial colonies. $\mathrm{pH}$ vermicast was determined according to the concentration of dissolved $\mathrm{H}^{+}$in water and measured using $\mathrm{pH}$ meter. Organic-C content was determined according to measurement on the intensity of the formed green color of $\mathrm{Cr}^{3+}$ due to orange $\mathrm{Cr}^{6+}$ was reduced by organic carbon under acid condition. The intensity of that green color was measured using a spectrophotometer at $561 \mathrm{~nm}$ wavelength. Total-N was determined using the Kjeldahl method and the intensity of formed indophenol blue color was measured using a spectrophotometer at $636 \mathrm{~nm}$ wavelength. Content of total-P $\left(\mathrm{P}_{2} \mathrm{O}_{5}\right)$ was determined using an extract of $\mathrm{HCl} 25 \mathrm{~N}$, and the intensity of appeared blue color due to the application of staining $\mathrm{P}$ reagent was measured using a spectrophotometer at $889 \mathrm{~nm}$ wavelength. All measurement methods for those chemical parameters followed the technical guidance of chemical analysis for soil, plant, water, and fertilizer published by Soil Research Institute (Eviati and Sulaeman 2009).

Morphological characters of the bacterial colony were identified by characterizing the bacterial culture on an agar plate (Pollack et al. 2009). A total of 10 grams of a composite sample from each 


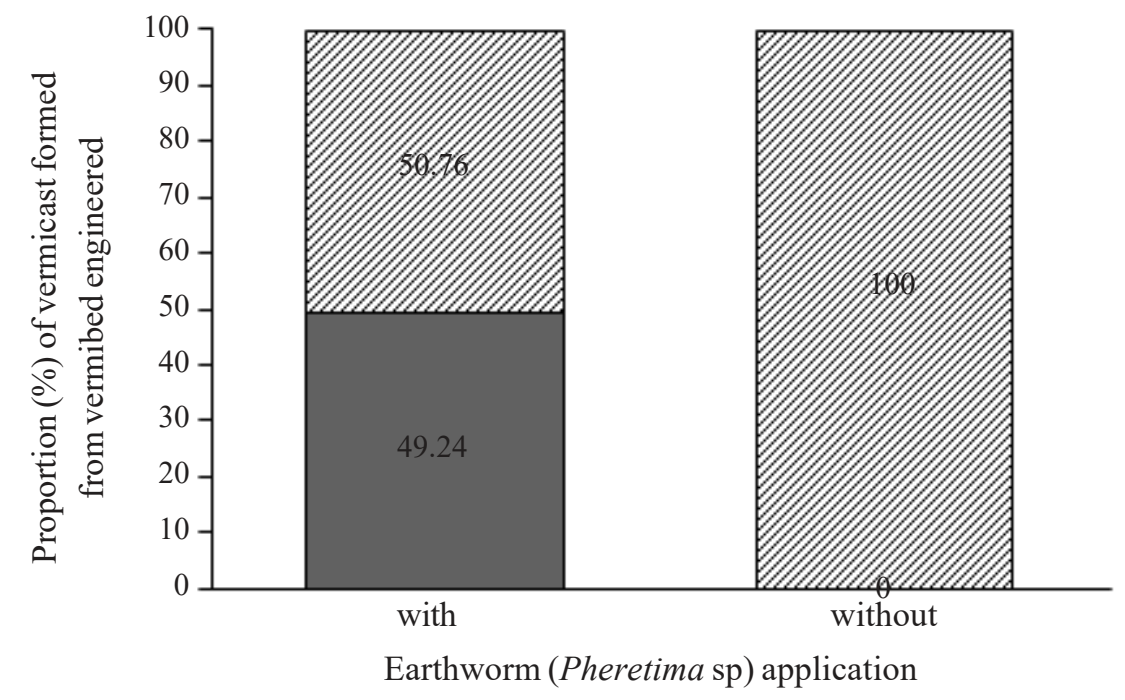

Figure 1. Proportion of vermicast from vermireactor tested with and without earthworm applied. $\square$ : Nonvermicast; $\square$ : Vermicast.

vermicast put in different Scoot bottle $250 \mathrm{ml}$, then added $100 \mathrm{ml}$ of sterile distilled water, and it was shaken using a reciprocal shaker for 24 hours (Germida and de Freites 2008). A total of $50 \mathrm{iL}$ of each diluted suspension $\left(10^{-8}\right.$ and $\left.10^{-9}\right)$ was spread on the culture medium Tryptic Soy Broth (TSA) in a different petri dish labeled with $\mathrm{K} 01, \mathrm{~K} 02, \mathrm{~K} 03, \ldots$, and K16. Each petri dish was incubated at room temperature for 48 hours. To obtain single colonies, the colonies formed on the TSA media were taken using the different needle and then transferred onto the TSA media surface in the other petri dish, and incubated for 48 hours under room temperature. The morphological characters of each colony formed were identified following the guidelines of Pollack et al. (2009).

\section{Statistical Analysis}

Variations in production and chemical quality of vermicast between main plots, subplots, and interactions were analyzed using analysis of variance (ANOVA) at the $p<0.05$ level. The homogeneity of the variance of each data was tested using the Levene Statistic at the $p>0.05$ level. The data did not meet the homogeneity of variance was transformed by $\sqrt{x+0.5}$, and still did not meet the data could be analyzed using the Kruskal-Wallis H test at the $p<0.05$ level. The difference among the treatments was used Least Significant Difference (LSD) test at the $p<0.05$ level. Variations in the number of forms of bacterial colony among different vermireactor-shape were analyzed using the descriptive approach.

\section{RESULTS AND DISCUSSION}

\section{Vermicast product}

Analysis of variance showed that the application of earthworm (Pheretima sp.) significantly affected $(\mathrm{p}<0.05)$ the percentage of successful vermibed converted into vermicast, whereas the shape of vermireactor and their interaction were not significant $(p>0.05)$. The result of the t-test (at $p=0.02$ level) revealed that the percentage of formed vermicast in vermireactor with the application of Pheretima sp. was higher than without Pheretima sp. for 28 days of vermicast process period (Figure 1).

Figure 1 illustrated that there was no vermicast formed in vermireactor without any application of Pheretima sp. ( $0 \%$ vermicast), while $49.24 \%$ of vermicast was produced with the application of Pheretima sp for 28 days of vermibed vermicasting process. In addition to composition and quality, moisture and aeration of vermibed, productivity of vermicast from a vermireactor was also highly determined by the ratio of surface area and volume of vermibed (Jain et al. 2003).

The area of two-dimensional figures of each vermireactor shape and tested height of vermibed in this experiment indicated that the ratio of surface area and vermibed volume in vermireactor made from two-dimensional figures of cylinder, square and rectangular were $0.50,0.52$, and 1.09 , respectively. By comparing those three ratios, it was recognized that ratios of surface area and vermibed volume in rectangular vermireactor were 2.10 and 2.18 times higher than those of square and cylinder vermireactor, respectively. Figure 2 showed that the 


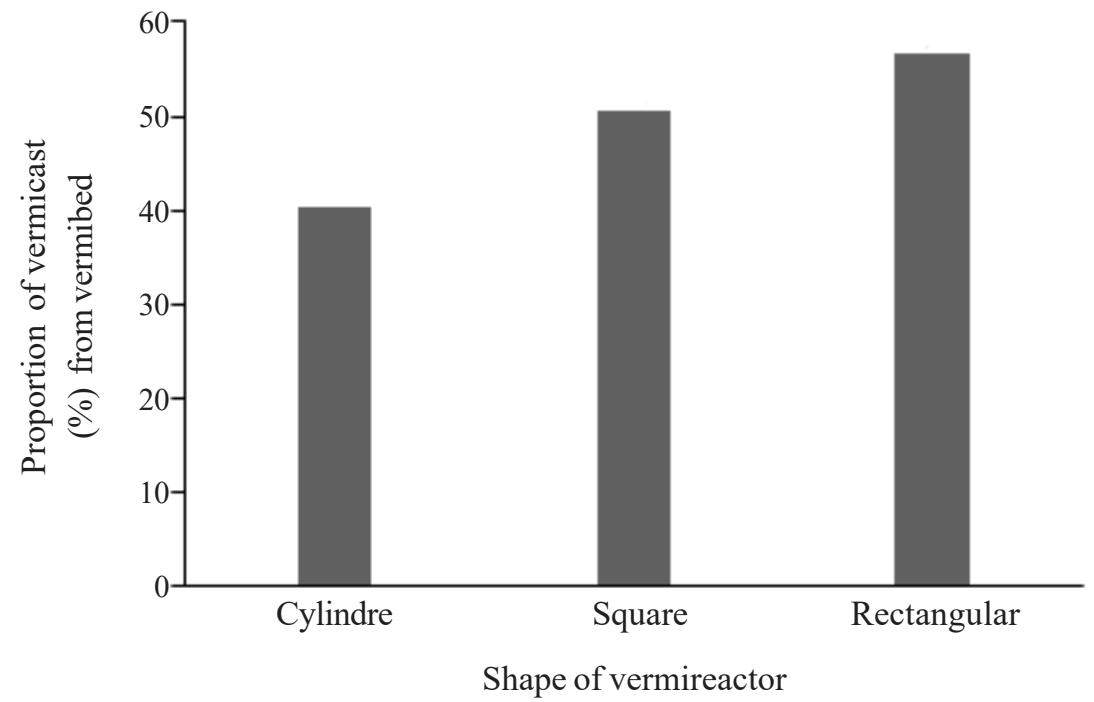

Figure 2. Proportion of cast from vermicast produced in cylinder, square and rectangular vermireactors.

production of vermicast tended to increase in the vermireactor cylinder, followed by square and rectangular. However, the difference in the proportion of successful vermibed converted into vermicast among those three vermireactors was not significant (at $\mathrm{p}>0.05$ level). This implied that the increment up to 2.18 times the ratio of surface area and vermibed volume in vermireactor could not significantly increase the vermicast production of Pheretima sp. yet. This fact indicated that the performance of Pheretima sp in producing vermicast in established vermireactors from three different two-dimensional figures (cylinder, square, and rectangular) with relatively same area was similar.

\section{Chemical Quality of the Vermicast}

Chemical indicators of the vermicast quality were measured through parameters of $\mathrm{pH}$, organic$\mathrm{C}$, total- $\mathrm{N}, \mathrm{C} / \mathrm{N}$ ratio, and $\mathrm{P}_{2} \mathrm{O}_{5}$ (extracted with $\mathrm{HCl}$ $25 \mathrm{~N}$ ). Effects of different vermireactor shapes on $\mathrm{pH}$ (ANOVA at the $\mathrm{p}=0.04$ ), total-N (KruskalWallis at the $\mathrm{p}=0.12$ level; $\mathrm{df}=2, \div 2=8.828$ ), and
$\mathrm{C} / \mathrm{N}$ ratio (Kruskal Wallis at the $\mathrm{p}=0.001$ level; $\mathrm{df}$ $\left.=2, \div^{2}=13.011\right)$ were significant, while organic-C (ANOVA at the $\mathrm{p}=0.101$ level) and $\mathrm{P}_{2} \mathrm{O}_{5}$ (KruskalWallis at the $\mathrm{p}=0.067$ level; $\mathrm{df}=2, \div^{2}=5.396$ ) were not significant. Comparison of $\mathrm{pH}$, organic-C, total- $\mathrm{N}, \mathrm{C} / \mathrm{N}$ ratio, and $\mathrm{P}_{2} \mathrm{O}_{5}$ in vermicast from different vermireactor shapes with the application of Pheretima sp was presented in Table 1.

The conversion process of vermibed by earthworms was always followed by the decomposition process of organic material. The release of $\mathrm{CO} 2$ to atmosphere occurred during the decomposition process of vermibed and also followed by the release of some organic acids into the soil environment (Amouei et al. 2017). These released organic acids were extremely potential to alternate $\mathrm{pH}$ substrate (Subramanian et al. 2010). Table 1 showed that $\mathrm{pH}$ vermicast produced from three vermireactors was $6.08-6.60$ in range. $\mathrm{pH}$ vermicast of cylinder vermireactor was the significant lowest among the other two shapes of vermireactor (at $\mathrm{p}<0.05$ level). This low $\mathrm{pH}$ value

Table 1. Comparison on values (mean $\pm \mathrm{sd}, \mathrm{n}=3$ ) of chemical parameters in vermicast among cylinder, square and rectangular vermireactors with Pheretima sp. as ecosystem engineers.

\begin{tabular}{lccc}
\hline \multirow{2}{*}{ Parameters of chemical quality } & \multicolumn{3}{c}{ Vermireactor shapes } \\
\cline { 2 - 4 } & Cylinder & Square & Rectangular \\
\hline $\mathrm{pH} \mathrm{H} \mathrm{H}_{2} \mathrm{O}(1: 2.5)$ & $6.08 \pm 0.33 \mathrm{a}$ & $6.17 \pm 0.32 \mathrm{~b}$ & $6.60 \pm 0.21 \mathrm{c}$ \\
Organic-C $(\%)$ & $0.50 \pm 0.15 \mathrm{a}$ & $0.49 \pm 0.34 \mathrm{a}$ & $0.80 \pm 0.39 \mathrm{a}$ \\
Total-N $(\%)$ & $0.11 \pm 0.04 \mathrm{~b}$ & $0.07 \pm 0.08 \mathrm{ab}$ & $0.04 \pm 0.02 \mathrm{a}$ \\
$\mathrm{C} / \mathrm{N}$ ratio & $4.74 \pm 1.63 \mathrm{a}$ & $11.67 \pm 6.52 \mathrm{~b}$ & $23.57 \pm 11.27 \mathrm{c}$ \\
$\mathrm{P}_{2} \mathrm{O}_{5}\left(\mathrm{mg} 100 \mathrm{~g}^{-1}\right.$ vermicast $)$ & $2.94 \pm 1.36 \mathrm{a}$ & $4.56 \pm 1.18 \mathrm{a}$ & $4.87 \pm 3.51 \mathrm{a}$ \\
\hline
\end{tabular}

Note: Number followed by arabic letters in different columns of the same row is significantly different at the $\mathrm{p}<0.05$ level. 
was assumed correlating with higher produced organic acids during the engineering process of vermibed by earthworms in-cylinder vermireactor than those of other shapes.

During the vermicast process in vermireactor, the activity of earthworm contributed to alteration on contents of organic-C, total- $\mathrm{N}$, as well as $\mathrm{C} / \mathrm{N}$ ratio in vermibed (Pramanik 2010; Huang et al. 2014). This research found that the difference in the number of organic-C of vermicast produced from three shapes of vermireactor was not significant at $p>0.05$ level (Table 1). In contrast, the content of the total-N of produced vermicast from the shape of the vermireactor was significantly different (at $\mathrm{p}<0.05$ level). Though, the difference in content of total-N vermicast from cylinder and square vermireactors was not significant (at $p>0.05$ level). Total-N of vermicast from each vermireactor compared to total-N vermicast from square vermireactor was significantly different at $\mathrm{p}<0.05$ level (Table 1). The difference in content of total-N vermicast among shapes of vermireactor might due to the difference in the content of $\mathrm{N}$-excreta (mucus and urine) produced by earthworm (Needham 1957; Salmon 2001). Value of $\mathrm{C} / \mathrm{N}$ ratio in vermicast from rectangular vermireactor was the highest and significantly different compared to other two vermireactors (at $p<0.05$ level), while the lowest $\mathrm{C} / \mathrm{N}$ ratio was from cylinder vermireactor, and this value was also significantly different (at $p<0.05$ level) compared to the value of $\mathrm{C} / \mathrm{N}$ ratio in vermicast from square vermireactor. These $\mathrm{C} / \mathrm{N}$ ratio values described that quality of vermicast produced from three shapes of vermireactor varied.

The difference in content of $\mathrm{P}_{2} \mathrm{O}_{5}$ in produced vermicast from each shape of the vermireactor was not significant at $p<0.05$ level (Table 1). Many other researchers reported that the content of total-P in vermicompost produced from rectangular vermireactor increased in comparison with the initial content of total-P in vermibed (Pramanik et al. 2007; Sharma and Garg 2018). This increment was possibly related to enzymatic activities (acid and alkaline phosphatase enzymes) from phosphate dissolving bacteria in gut and cast of earthworms which were capable of releasing phosphorus (Jones and Oburger 2011; Soobhany et al. 2015). In this research, the content of $\mathrm{P}$ from vermicast was extracted using strong acid $(\mathrm{HCl} 25 \mathrm{~N})$, and this result showed that difference in the content of $\mathrm{P} 2 \mathrm{O} 5$ in vermicast from three shapes of vermireactor was not significant at $p$ $>0.05$ level (Table 1). This fact explained the possibility that the performance of Pheretima sp. to stimulate the activity of acid and alkaline phosphatase enzymes producing microbial population was similar in three shapes of vermireactor.

\section{Number of Bacterial Colonies}

A total of sixteen morphological types of the bacterial colony was identified in vermicast produced from three different shapes of vermireactors at the 28 days after the vermibed engineered by earthworm (Pheretima sp.) activity. The various morphological types of the bacterial colony were presented in Table 2.

Many heterotrophic bacteria in vermicast could be cultured under laboratory conditions (Olsen and Bakken 1987). Morphological characteristics of an established bacterial colony in a cultural medium might be used to represent their environmental condition and biochemical history (Cooper et al. 1968). Such characteristics could be utilized to explain the relationship between physicochemical conditions and bacterial diversity on the substrate, especially vermicast (Lebaron et al. 1998; Franklin et al. 2001). The richness in the type of morphological colony was also frequently used to represent the alteration on bacterial diversity due to the change of physicochemical conditions in vermicast (Müller et al. 2002). Physicochemical factors, such as $\mathrm{pH}$, organic- $\mathrm{C}$, and $\mathrm{C} / \mathrm{N}$ ratio of substrate were positively correlated with the richness of bacteria (Ge et al. 2010).

Table 2 showed that there were three-, eleven-, and six-morphological types of bacterial colonies found in vermicast produced from a cylinder, square, and rectangular vermireactors, respectively. Morphological colony of K09 and K10 types were only observed in vermicast produced from cylinder vermireactor, K14, K15, and K16 types were solely found in vermicast of rectangular vermireactor, and morphological types noticed with K01, K02, K03, $\mathrm{K} 04, \mathrm{~K} 05, \mathrm{~K} 06, \mathrm{~K} 07$, and $\mathrm{K} 08$ were merely found in vermicast of square vermireactor. The morphological type of K13 was found in vermicast produced from all shapes of the vermireactor. $\mathrm{Wu}$ et al. (2017) reported that $\mathrm{pH}$ substrate was an important factor in establishing the richness of bacteria. Thus, it could be explained that variation in the morphological colony of bacteria occurring among shapes of vermireactor was strongly related to a significant difference in $\mathrm{pH}$ of vermicast among vermireactors. The richness of bacterial species was the highest at near-neutral $\mathrm{pH}$ and slightly decreased from near-neutral $\mathrm{pH}$ to alkaline $\mathrm{pH}$ (Zhang et al. 2017). The value of the $\mathrm{C} / \mathrm{N}$ ratio was one of the indicators for the quality of substrate associating with the availability of carbon and nitrogen for the growth of various bacteria (de Menezes et al. 2015). A low value of the $\mathrm{C} / \mathrm{N}$ ratio enabled the substrate to produce higher ammonia restricting the growth of various bacterial populations, whereas high ratio 
Table 2. Morphological type of bacterial colony identified in vermicast during 28 days of vermibed modified in the different of vemireactor shape.

\begin{tabular}{|c|c|c|c|c|c|c|c|c|c|}
\hline \multirow[t]{2}{*}{$\begin{array}{l}\text { Sample } \\
\text { code }\end{array}$} & \multicolumn{6}{|c|}{ Morphological characteristics of the bacterial colony } & \multicolumn{3}{|c|}{$\begin{array}{l}\text { Presence of the bacterial colony } \\
\text { type from cast produced by } \\
\text { different vermireactor shape }\end{array}$} \\
\hline & Shape & Margin & Elevation & Opacity & Colour & Surface & Cylinder & Square & Rectangular \\
\hline K01 & Irregular & Undulate & Flat & Opaque & Grayish-white & Rough & 0 & 1 & 0 \\
\hline K02 & Irregular & Undulate & Flat & Slightly & White opaque & Rough & 0 & 1 & 0 \\
\hline K03 & Irregular & Lobate & Umbonate & Slightly opaque & White brown & Rough & 0 & 1 & 0 \\
\hline K04 & Circular & Entire & Flat & Slightly opaque & White opaque & Bit rough & 0 & 1 & 0 \\
\hline K05 & Irregular & Undulate & Crater form & Opaque & White opaque & Bit rough & 0 & 1 & 0 \\
\hline K06 & Circular & Entire & Flat & Transculent & Yellow & Smooth & 0 & 1 & 0 \\
\hline K07 & Circular & Entire & Raised & Opaque & White brownish & Smooth & 0 & 1 & 0 \\
\hline K08 & Circular & Entire & Raised & Slightly opaque & Bright yellowish & Smooth & 0 & 1 & 0 \\
\hline K09 & Irregular & Lobate & Crater form & Slightly opaque & White opaque & Rough & 1 & 0 & 0 \\
\hline K10 & Irregular & Undulate & Crater form & Slightly opaque & White & Rough & 1 & 0 & 0 \\
\hline K11 & Irregular & Undulate & Flat & Slightly opaque & White opaque & Rough & 0 & 1 & 1 \\
\hline $\mathrm{K} 12$ & Circular & Entire & Raised & Opaque & Cream & Smooth & 0 & 1 & 1 \\
\hline K13 & Circular & Entire & Raised & Slightly opaque & Cream & Smooth & 1 & 1 & 1 \\
\hline K14 & Circular & Entire & Raised & Slightly opaque & Brownish white & Smooth & 0 & 0 & 1 \\
\hline K15 & Circular & Entire & Flat & Slightly opaque & White opaque & Smooth & 0 & 0 & 1 \\
\hline K16 & Irregular & Undulate & Umbonate & Slightly opaque & White opaque & Rough & 0 & 0 & 1 \\
\hline Total & & & & & & & 3 & 11 & 6 \\
\hline
\end{tabular}

Note: 1 is indicated present; 0 is indicated absent; $\mathrm{K}$ is symbol of petridish where bacteria grown on TSA medium

caused the shortage of available nitrogen for supporting the growth of various bacteria (Egli and Quayle 1986). Based on $\mathrm{C} / \mathrm{N}$ ratio in those vermicasts (Table 1), it could be expressed that the lowest number of morphological types in the bacterial colony in vermicast of cylinder vermireactor might be caused by high production of ammonia, which might inhibit the bacterial growth (Leejeerajumnean et al. 2000). Number in types of morphological colony in vermicast from rectangular vermireactor was more than vermicast from cylinder vermireactor, and less than that in vermicast from square vermireactor. Such findings were probably due to the availability of nitrogen limiting the growth of various bacteria. The number of colony morphotypes in vermicast from square vermireactor might be highly associated with the balanced availability of carbon and nitrogen in vermicast enabling the growth of various bacterial populations (Mooshammer et al. 2014). It indicated that the shape of the vermireactor had an implication on the diversity of bacterial morphotypes in vermicast.

\section{CONCLUSIONS}

Production of vermicast from earthworm (Pheretima sp.) using a mixture of soil from land with $C$. odorata vegetation and compost of pruned $C$. odorata as vermibed was similar between reactor in forms of cylinder, square and rectangular.
The difference in chemical quality of produced vermicast from various shapes of vermireactor can be found on $\mathrm{pH}$, total- $\mathrm{N}$, and $\mathrm{C} / \mathrm{N}$ ratio. Variation on morphological characters of bacteria in vermicast from Pheretima sp. produced by square vermireactor was more than the cylinder and rectangular vermireactors.

\section{ACKNOWLEDGEMENTS}

We would like to thanks the Ministry of Research, Technology, and Higher Education of the Republic Indonesia that has funded this research through the National Strategic (STRANAS) with contract number: 147/SP2H/LT/DRPM/III/2016. Also to everyone who has assisted in the laboratory and field.

\section{REFERENCES}

Aalok A, AK Tripathi and P Soni. 2008. Vermicomposting: a better option for organic solid waste management. $J$ Hum Ecol 24: 59-64. doi:10.1080/09709274. 2008.11906100.

Aira M, M Gómez-Brandón, P González-Porto and J Domínguez. 2011. Selective reduction of the pathogenic load of cow manure in an industrialscale continuous-feeding vermireactor. Bioresource Technol 102: 9633-9637. doi:10.1016/j.biortech. 2011.07.115. 
Amouei AL, Z Yousefi and T Khosrafi. 2017. Comparison of vermicompost characteristics produced from sewage sludge of wood and paper industry and household solid wastes. J Environ Health Sci 15: 1-6. doi:10.1186/s40201-017-0269-z.

Cooper AL, ACR Dean and C Hinshelwood. 1968. Factors affecting the growth of bacterial colonies on agar plates. Proc Royal Soc B: Biological Sci 171: 175199. doi:10.1098/rspb.1968.0063.

de Menezes AB, MT Prendergast-Miller, P Poonpatana, M Farrell, A Bissett, MM Macdonald, P Toscas, AE Richardson and $\mathrm{PH}$ Thrall. 2015. C/N ratio drives soil actinobacterial cellobiohydrolase gene diversity. Appl Environ Microbiol 81: 3016-3028. doi:10.1128/ AEM.00067-15.

Douds Jr, DD, J Lee, J Uknalis, AA Boateng and C ZieglerUlsh. 2014. Pelletized biochar as a carrier for AM fungi in the on-farm system of inoculum production in compost and vermiculite mixture. Compost Sci Util 22: 253-262. doi:10.1080/1065657X.2014.941515.

Edwards CA and KE Fletcher. 1988. Interactions between earthworms and micro-organisms in organic-matter breakdown. Agr Ecosyst Environ 24: 235-247. doi:10.1016/0167-8809(88)90069-2.

Egli Th and JR Quayle. 1986. Influence of the carbon:nitrogen ratio of the growth medium on the cellular composition and the ability of the methylotrophic yeast Hansenula polymorpha to utilize mixed carbon sources. J Gen Microbiol 132: 1779-1788. doi:10.1099/00221287-132-7-1779.

Eviati and Sulaeman. 2009. Petunjuk Teknis Analisis Kimia Tanah, Tanaman, Air, dan Pupuk, 2nd ed., Balai Penelitian Tanah, Departemen Pertanian Republik Indonesia. (in Indonesian).

Formowitz B, F Elango, S Okumoto, T Müller andABuerkert. 2007. The role of "effective microorganisms" in the composting of banana (Musa ssp.) residues. J Plant Nutr Soil Sci 170: 649-656. doi:10.1002/jpln.200700002.

Franklin RB, JL Garland, CH Bolster and AL Mills. 2001. Impact of dilution on microbial community structure and functional potential: comparison of numerical simulations and batch culture experiments. Appl Environ Microb 67: 702-712. doi:10.1128/ AEM.67.2.702.

Ganesh PS, S Gajalakshmi and SA Abbasi. 2009. Vermicomposting of the leaf litter of acacia (Acacia auriculiformis): Possible roles of reactor geometry, polyphenols, and lignin. Bioresource Technol 100: 1819-1827. doi:10.1016/j.biortech. 2008.09.051.

Ge Y, C Chen, Z Xu, SM Eldridge, KY Chan, Y He and J-Z He. 2009. Carbon/nitrogen ratio as a major factor for predicting the effects of organic wastes on soil bacterial communities assessed by DNA-based molecular techniques. Environ Sci Pollut Res 17: 807815. doi:10.1007/s11356-009-0185-6.

Germida JJ and JR de Freites. 2008. Cultural methods for soil and root-associated microorganisms. In: MR Carter and EG Gregorich (eds). Soil Sampling and Methods of Analysis. Canadian Society of Soil Science, pp. 341-347.
Hanc A and F Vasak. 2014. Processing separated digestate by vermicomposting technology using earthworms of the genus Eisenia. Int J Environ Sci Technol 12: 1183-1190. doi:10.1007/s13762-0140500-8.

Hanc A and P Pliva. 2013. Vermicomposting technology as a tool for nutrient recovery from kitchen biowaste. J Mater Cycles Waste Man 15: 431-439. doi:10.1007/s10163-013-0127-8.

Harinikumar KM and DJ Bagyaraj. 1994. Potential of earthworms, ants, millipedes, and termites for dissemination of vesicular-arbuscularmycorrhizal fungi in soil. Biol Fertil Soils 18: 115-118. doi:10.1007/BF00336456.

Hoeffner K, C Monard, M Santonja and D Cluzeau. 2018. Feeding behaviour of epi-anecic species and their impact on soil microbial communities. Soil Biol Biochem 125: 1-9. doi:10.1016/j.soilbio.2018.06.017.

Huang K, F Li, Y Wei, X Fu and X Chen. 2014. Effects of earthworms on physicochemical properties and microbial proûles during vermicomposting of fresh fruit and vegetable wastes. Bioresour Technol 170: 45-52. doi:10.1016/j.biortech.2014.07.058.

Jain K, J Singh and SK Gupta. 2003. Development of a modified vermireactor for efficient vermicomposting: a laboratory study. Bioresour Technol 90: 335-337. doi:10.1016/S0960-8524(03)00048-8.

Jones CG, JH Lawton and M Shachak. 1994. Organisms as ecosystem engineers. Oikos 69: 373-386. doi: $10.2307 / 3545850$.

Jones DL and E Oburger. 2011. Solubilization of phosphorus by soil microorganisms. In: EK Bünemann, A Oberson and E Frossard (eds). Phosphorous in Action: Biological Processes in Soil Phosphorous Cycling, 26. Springer-Verlag, Berlin Heidelberg, pp. 169-198. doi:10.1007/978-3642-15271-9.

Jouquet P, J Dauber, J Lagerlöf, P Lavelle and M Lepage. 2006. Soil invertebrates as ecosystem engineers: intended and accidental effects on soil and feedbacks loops. Appl Soil Ecol 32: 153-164. doi:10.1016/j.apsoil.2005.07.004.

Kilowasid LMH, Herlina, H Syaf, LO Safuan, M Tufaila, S Leomo and B Widiawan. 2015. Engineering of soil biological quality from nickel mining stockpile using two earthworm ecological groups. J Degraded Mining Land Manage 2: 361-367. doi:10.15243/ jdmlm.2015.023.361.

Lavelle P, A Spain, M Blouin, G Brown, T Decaëns, Grimaldi, J Jiménez, D Mckey, J Mathieu,E Velasquez and A Zangerlé. 2016. Ecosystem engineers in a self-organized soil: a review of concepts and future research questions. Soil Sci 81: 91-109. doi:10.1097/ SS.0000000000000155.

Lazcano C, M Gómez-Brandón and J Domínguez. 2008. Comparison of the effectiveness of composting and vermicomposting for the biological stabilization of cattle manure. Chemosphere 72: 1013-1019. doi:10.1016/j.chemosphere.2008.04.016. 
Lebaron P, JF Ghiglione, C Fajon, N Batailler and P Normand. 1998. Phenotypic and genetic within a colony morphotype. FEMS Microbiol Lett 160: 137143. doi:10.1111/j.1574-6968.1998.tb12903.x.

Leejeerajumnean A, JM Ames and JD Owens. 2000. Effect of ammonia on the growth of Bacillus species and some other bacteria. Lett Appl Microbiol 30: 385389. doi:10.1046/j.1472-765x.2000.00734.x.

Mooshammer M, W Wanek, I Hämmerle, L Fuchslueger, F Hofhansl, A Knoltsch, J Schnecker, M Takriti,M Watzka, B Wild, KM Keiblinger, S Keiblinger and A Richter. 2014. Adjustment of microbial nitrogen use efficiency to carbon:nitrogen imbalances regulates soil nitrogen cycling. Nat Commun 5: 3694. doi:10.1038/ncomms4694.

Mora P, C Seuge, JP Rossi, and C Rouland. 2006. Abundance of biogenic structures of earthworm and termites in a mango orchard. Eur J Soil Biol 42: 250-253. doi:10.1016/j.ejsobi.2006.07.023.

Muller AK, K Westergaard, S Christensen and SJ Sørensen. 2002. The diversity and function of soil microbial communities exposed to different disturbances. Microb Ecol 44: 49-58. doi:10.1007/ s00248-001-0042-8.

Nair J, V Sekiozoic and M Anda. 2006. Effect of precomposting on vermicomposting of kitchen waste. Bioresour Technol 97: 2091-2095. doi:10.1016/ j.biortech.2005.09.020.

Needham AE. 1957. Components of nitrogenous excreta in the earthworms Lumbricus terrestris L. and Eisenia foetida (Savigny). J Exp Biol 34: 425-446.

Nigussie A, TW Kuyper, S Bruun and A de Neergaard. 2016. Vermicomposting as a technology for reducing nitrogen losses and greenhouse gas emissions from small-scale composting. J Clean Prod 139: 429-439. doi:10.1016/j.jclepro.2016.08.058.

Olsen RA and LR Bakken. 1987. Viability of soil bacteria: optimization of plate-counting technique and comparison between total counts and plate counts within different size groups. Microb Ecol 13: 59-74. doi:10.1007/BF02014963.

Pandya U, D Maheshwari and M Saraf. 2014. Assessment of ecological diversity of rhizobacterial communities in vermicompost and analysis of their potential to improve plant growth. Biologia 69: 968-976. doi:10.2478/s11756-014-0406-4.

Pathma J and N Sakthivel. 2012. Microbial diversity of vermicompost bacteria that exhibit useful agricultural traits and waste management potential. Springerplus 1:26. doi:10.1186/2193-1801-1-26.

Pollack RA, L Findlay, W Mondschein and RR Modesto. 2009. Laboratory exercises in microbiology (3rd ed.). John Wiley \& Sons, Inc.

Pramanik P, GK Ghosh, PK Ghosal and P Banik. 2007. Changes in organic - C, N, P and K and enzyme activities in vermicompost of biodegradable organic wastes under liming and microbial inoculant. Bioresource Technol 98: 2485-2494. doi:10.1016/ j.wasman.2009.12.007.
Pramanik P. 2010. Changes in microbial properties and nutrient cycling in bagasse and coir during vermicomposting: quantification of fungal biomass through ergosterol estimation in vermicompost. Waste Manage 30: 787-791. doi:10.1016/ j.biortech.2006.09.017.

Raphael K and K Velmourougane. 2011. Chemical and microbiological changes during vermicomposting of coffee pulp using exotic (Eudrilus eugeniae) and native earthworm (Perionyx ceylanesis) species. Biodegradation 22: 497-507. doi:10.1007/s10532010-9422-4.

Reddell P and AV Spain. 1991. Earthworms as vectors of viable propagules of mycorrhizal fungi. Soil Biol Biochem 23: 767-774. doi:10.1016/00380717(91)90147-C.

Rekha GS, PK Kaleena, D Elumalai, MP Srikumaran and VN Maheswari. 2018. Effects of vermicompost and plant growth enchancer in the exo-morphological features of Capsicum annum (Linn.) Hepper. Int J Recycl Org Waste Agric 7: 83-88. doi:10.1007/s40093017-0191-5.

Salmon S. 2001. Earthworm excreta (mucus and urine) affect the distribution of springtails in forest soil. Biol Fertil Soils 34: 304-310. doi:10.1007/ s003740100407.

Sekar KR and N Karmegam. 2010. Earthworm casts as an alternate carrier material for biofertilizers: Assessment of endurance and viability of Azotobacter chroococcum, Bacillus megaterium and Rhizobium leguminosarum. Sci Hortic 124: 286289. doi:10.1016/j.scienta.2010.01.002.

Sharma K and VK Garg. 2018. Comparative analysis of vermicompost quality produced from rice straw and paper waste employing earthworm Eisenia fetida (Sav.). Bioresour Technol 250: 708-715. doi:10.1016/ j.biortech.2017.11.101.

Sim EYS and TY Wu. 2010. The Potential Reuse of Biodegradable Municipal Solid Wastes (MSW) as Feedstocks in Vermicomposting. J Sci Food Agr 90: 2153-2162. doi:10.1002/jsfa.4127.

Singh RP, P Singh, ASF Araujo, MH Ibrahim and O Sulaiman. 2011. Management of urban solid waste: vermicomposting a sustainable option. Resour Conserv Recyc 5: 719-729. doi:10.1016/ j.resconrec.2011.02.005.

Singh S, J Singh and AP Vig. 2016. Earthworms as ecological engineers to change the physicochemical properties of soil: soil vs vermicast. Ecol Eng 90: 1-5. doi:10.1016/j.ecoleng.2016.01.072.

Soobhany N, R Mohee and VK Garg. 2015. Recovery of nutrient from municipal solid waste by composting and vercomposting using earthworm Eudrilus eugeniae. J Environ Chem Eng 3: 2931-2942. doi:10.1016/j.jece.2015.10.025.

Subramanian S, M Sivarajan and S Saravanapriya. 2010. Chemical changes during vermicomposting of sago industry solid waste. J Hazard Mater 179: 318-322. doi:10.1016/j.jhazmat.2010.03.007. 
Tognetti C, F Laos, MJ Mazzarino and MT Hernandez. 2005. Composting vs vermicomposting: a comparison of end product quality. Compost Sci Util 13: 6-13. doi:10.1080/1065657X.2005.10702212.

Vijayabharathi R, A Sathya and S Gopalakhrisnan. 2015. Plant growth-promoting microbes from herbal vermicompost. In: D Egamberdieva, S Shrivastava and A Varma (eds). Plant-growth-promoting rhizobacteria (PGPR) and medicinal plants. Springer International Publishing, Switzerland, pp. 71-88. doi:10.1007/978-3-319-13401-7.
Wodika BR, RP Klopf and SG Baer. 2014. Colonization and recovery of invertebrate ecosystem engineers during prairie restoration. Restor Ecol 22: 456-464. doi:10.1111/rec.12084.

Wu Y, J Zeng, Q Zhu, Z Zhang and X Lin. 2017. pH is the primary determinant of the bacterial community structure in agricultural soils impacted by polycyclic aromatic hydrocarbon pollution. Sci Rep 7: 40093. doi:10.1038/srep40093.

Zhang Y, H Shen, X He, BW Thomas, NZ Lupwayi, X Hao, S Xi. 2017. Fertilization shapes bacterial community structure by alteration of soil pH. Front Microbiol 8: 1325. doi:10.3389/fmicb.2017.01325. 